M. LOHMUS, O. PARVE, Anne MURAUS,

M. LOPP, U. LILLE

\title{
RESOLUTION OF E- AND Z-ISOMERS OF PROSTACYCLIN CARBA-ANALOGS BY HIGH PERFORMANCE LIQUID CHROMATOGRAPHY
}

Since 1976, when prostacyclin was discovered [1], its remarkable biological properties have stimulated intense research into the preparation of stable synthetic analogs for therapeutic use $\left[{ }^{2,3}\right]$. Among them, the carba-analogs of prostacyclin are of considerable importance [4]. As both the $E$ - and $Z$-isomers of different biological activity are formed in the Wittig olefination, one of the key steps in carbacyclin synthesis [ $\left.{ }^{3}\right]$, methods for their separation are highly needed. Up to now, only R. F. Newton and A. H. Wadsworth $\left.{ }^{[5}\right]$ have used the HPLC method for determining the ratio of $E / Z$-isomers of some prostacyclin carbaanalogs.

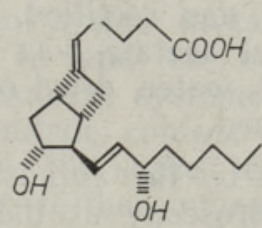

(5E)-9-desoxy- $\Delta^{5}-6,9 \alpha$-cyclo-PGF 1

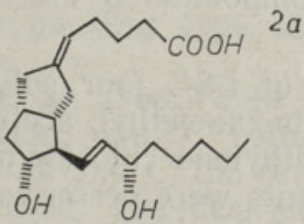

(5Z) -9-desoxy-6,9 $\alpha$-methano- $\Delta^{5}-\mathrm{PGF}_{1}$

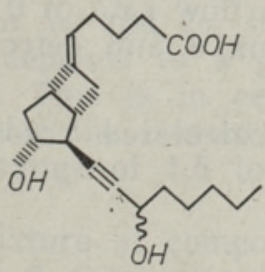

(5E) -9-desoxy-13,14-didehydro$15 \alpha / \beta-\Delta^{5}-6,9 \alpha-$ cyclo-PGF 1

$3 a$

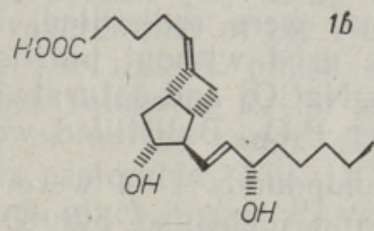

(5Z)-9-desoxy- $\Delta^{5}-6,9 \alpha$-cyclo-PGF 1

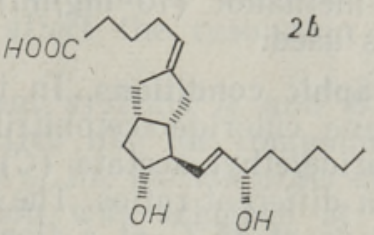

(5E)-9-desoxy-6,9a-methano- $\Delta^{5}-\mathrm{PGF}_{1}$

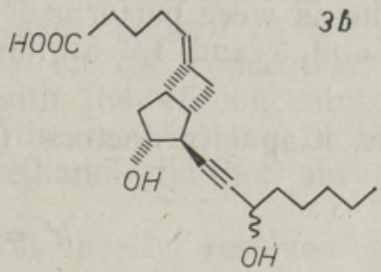

(5Z)-9-desoxy-13,14-didehydro$15 \alpha / \beta-\Delta^{5}-6,9 \alpha$-cyclo-PGF 1 


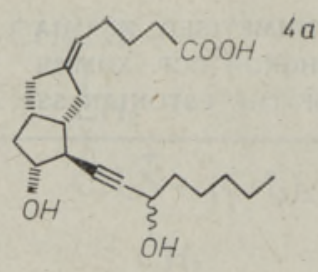

(5Z) -9-desoxy-13,14-didehydro$15 \alpha / \beta-6,9 \alpha$-methano- $\Delta^{5}-\mathrm{PGF}_{1}$

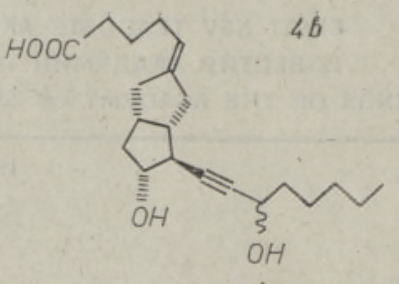

(5E) -9-desoxy-13,14-didehydro$15 \alpha / \beta-6,9 \alpha-$ methano- $\Delta^{5}-\mathrm{PGF}_{1}$

We have studied the possibilities of separating the $E / Z$-isomers of four different carba-analogs $(1-4)$ of prostacyclin by liquid-solid (LSC) and reverse-phase mode bonded phase (BPC) chromatography.

\section{Materials and methods}

Apparatus. A DuPont HPLC system N 8845 with a UV spectrophotometrical detector was used.

Columns. Zorbax SIL, $4.6 \times 250 \mathrm{~mm}$ (DuPont) 1; Zorbax SIL, $6.0 \times 150$ $\mathrm{mm} 2$ and Silasorb $600(5 \mu \mathrm{m}), 6.0 \times 150 \mathrm{~mm} 3$ packed in the Special Designing Bureau (SDB), Tallinn, were used in the LSC studies.

Zorbax ODS, $4.6 \times 250 \mathrm{~mm}$ (DuPont) 4; Zorbax C-8, 4.6×250 mm (DuPont) 5 and Zorbax ODS, $6.0 \times 150 \mathrm{~mm} 6$ packed in the SDB were used in the BPC studies.

Solvents. All solvents were supplied by Reakhim. Methylene chloride and methanol were redistilled, acetonitrile was rectified. Hexane and $\mathrm{H}_{3} \mathrm{PO}_{4}$ were used without purification. Ethyl acetate was washed with aqueous $5 \%, \mathrm{NaCO}_{3}$ and saturated with $\mathrm{CaCl}_{2}$ water, dried on $\mathrm{K}_{2} \mathrm{CO}_{3}$ and distilled over $\mathrm{P}_{2} \mathrm{O}_{5}$. Bidistilled water was used.

Samples. Compounds $1-4$ were synthesized by the authors of the present work and identified by ${ }^{13} \mathrm{C}-\mathrm{NMR}$ spectroscopy at the Institute of Chemical Physics and Biophysics, Tallinn. By LSC, samples were converted into $p$-bromophenacyl esters according to $\left[{ }^{6,7}\right]$ and injected in methylene chloride $(1 \mathrm{mg} / \mathrm{ml})$. In the case of BPC the samples were injected in methanol $(10 \mathrm{mg} / \mathrm{ml})$. For compounds 3 and 4 the $15 \alpha / \beta$ mixture was used.

Chromatographic conditions. In the case of LSC four solvent systems, viz. methylene chloride/acetonitrile $(A)$, hexane/ethyl acetate $(B)$, methylene chloride/ethyl acetate $(C)$ and methylene chloride/methanol $(D)$ were used in different ratios. The experiments were performed at ambient temperature or at $35^{\circ} \mathrm{C}$ at a flow rate of $0.6 \mathrm{ml} / \mathrm{min}$ for column 1 and $1.0 \mathrm{ml} / \mathrm{min}$ for columns 2 and 3 and detected at $260 \mathrm{~nm}$.

In the case of BPC the varied content of acetonitrile or methanol in aqueous $0.017 \mathrm{M} \mathrm{H}_{3} \mathrm{PO}_{4}$ was used (solvent system $E$ and $F$, respectively). The experiments were performed at $35^{\circ}$ at a flow rate of $0.8 \mathrm{ml} / \mathrm{min}$ for columns 4 and 5 and $1.0 \mathrm{ml} / \mathrm{min}$ for column 6 and detected at 208$210 \mathrm{~nm}$.

Calculations. Capacity factors $\left(k^{\prime}\right)$ were calculated according to the formula

$$
k^{\prime}=\frac{t_{R}-t_{0}}{t_{0}}
$$

where $t_{R}$ - retention time (measured from the chromatogram, nm), $t_{0}-$ retention time of the unretained compound $(\mathrm{mm}) . t_{0}$ was calculated from 
operational values of the void volume of column $\left(V_{0}\right)$, chart speed and flow rate. For reverse phase columns $V_{0}$ was determined as the elution volume of $\mathrm{KNO}_{3}$ (for 4,5 and 6 it was 2.04, 1.85 and $2.08 \mathrm{ml}$, respectively). For the column 1 pore volume was calculated as $2.41 \mathrm{ml}$ according to [8]. The elution volume of the first eluted nonpolar compound was $2.68 \mathrm{ml}$. It means that the «true» void volume $2.41<V_{0} \leqslant 2.68$. Therefore, $V_{0}$ was taken as $2.68 \mathrm{ml}$, and $V_{0}$ for 2 and 3 as $2.74 \mathrm{ml}$ in the same way.

The resolution factors $((\alpha)$ were calculated according to the formula:

$$
\alpha=k_{b}^{\prime} / k_{a}^{\prime},
$$

where $k_{b}^{\prime}$ - capacity factor of the compound $b, k_{a}^{\prime}$ - capacity factor of the respective compound $a$. The resolution function $\left(R_{s}\right)$ was estimated according to $\left[{ }^{8}\right]$.

\section{Results and discussion}

The resolution of $E / Z$-isomers of prostacyclin analogs as their p-bromophenacyl ester is a complicated problem due to their very similar behaviour on silica gel. It means that the differences in specific interactions between $E / Z$-isomers, solvents and the adsorbent are very small.

Compounds 1 and 2 were chosen as model compounds in the elucidation of the possibilities of separating the $E / Z$-isomers of prostacyclin analogs. The results for $1 a$ and $1 b p$-bromophenacyl esters in the case of LSC are given in Table 1 . According to these results $1 a$ and $1 b$ are fairly separable in methylene chloride-acetonitrile $(A)$ and hexane-ethyl acetate $(B)$, with methylene chloride ethyl acetate $(C)$ being ineffective. For each solvent system investigated the reversibility of the elution orderof compound $1 a$ and $1 b$, occurs when the mobile phase content is changed. For solvent system $A$, the proper values of $R_{s}$ lie in the area with an acetonitrile content below $12 \%$ or in the range of $50-70 \%$. In the first case the higher temperature is preferable (Fig. 1A), whereas in the second case the ambient temperature gives higher $R_{s}$ values (Fig. $1 B)$. For solvent system $B$ a higher temperature $\left(35^{\circ}\right)$ decreases peak tailing and results in lower $k^{\prime}$ values (shorter analysis time) and better resolution (Fig. 1C).

The same $\alpha$ values were obtained for column 3 . We conclude that a change in the packing type does not affect the resolution selectivity of $E / Z$-isomers.

For $2 a$ and $2 b$ (see Table 2), solvent systems $A$ and $B$ gave the desired resolution, with $C$ being ineffective like for compounds 1. For solvent systems $A$ and $C$, the reversibility of the elution order of $2 a$ and $2 b$ was also observed. The desired resolution was achieved at the acetonitrile content below $20 \%$ (Fig. $2 A$ ), but the solvent system $B$ is preferable at a higher temperature $\left(35^{\circ}\right)$ due to shorter elution time (Fig. $2 B$ ).

Consequently, in the resolution of $p$-bromophenacyl esters of $1 a$ and $1 b$, and also of $2 a$ and $2 b$, the elution order as well as the selectivity of resolution depends to a great degree on the concentration of the mobile phases. This is in accordance with the «B-concentration rule» [ ${ }^{8}$ ], but only for the solvent system $D$ the reversibility of the elution order in the range of 1.5 to $5 \%$ of methanol did not obey this rule (Table 3).

The E/Z-mixture of compounds 3 was easily resolved using the solvent system $A$ (separation on $15 \alpha / \beta$-isomers also occurs). Conditions for compounds 3: column 1; methylene chloride/acetonitrile $=90 / 10 \mathrm{v} / \mathrm{v}$; $k_{3 a}^{\prime}=4.8$ and $5.1 ; k_{3 b}^{\prime}=5.2$ and $5.5(15 \alpha / \beta$-isomers of 3 and 4 were not 


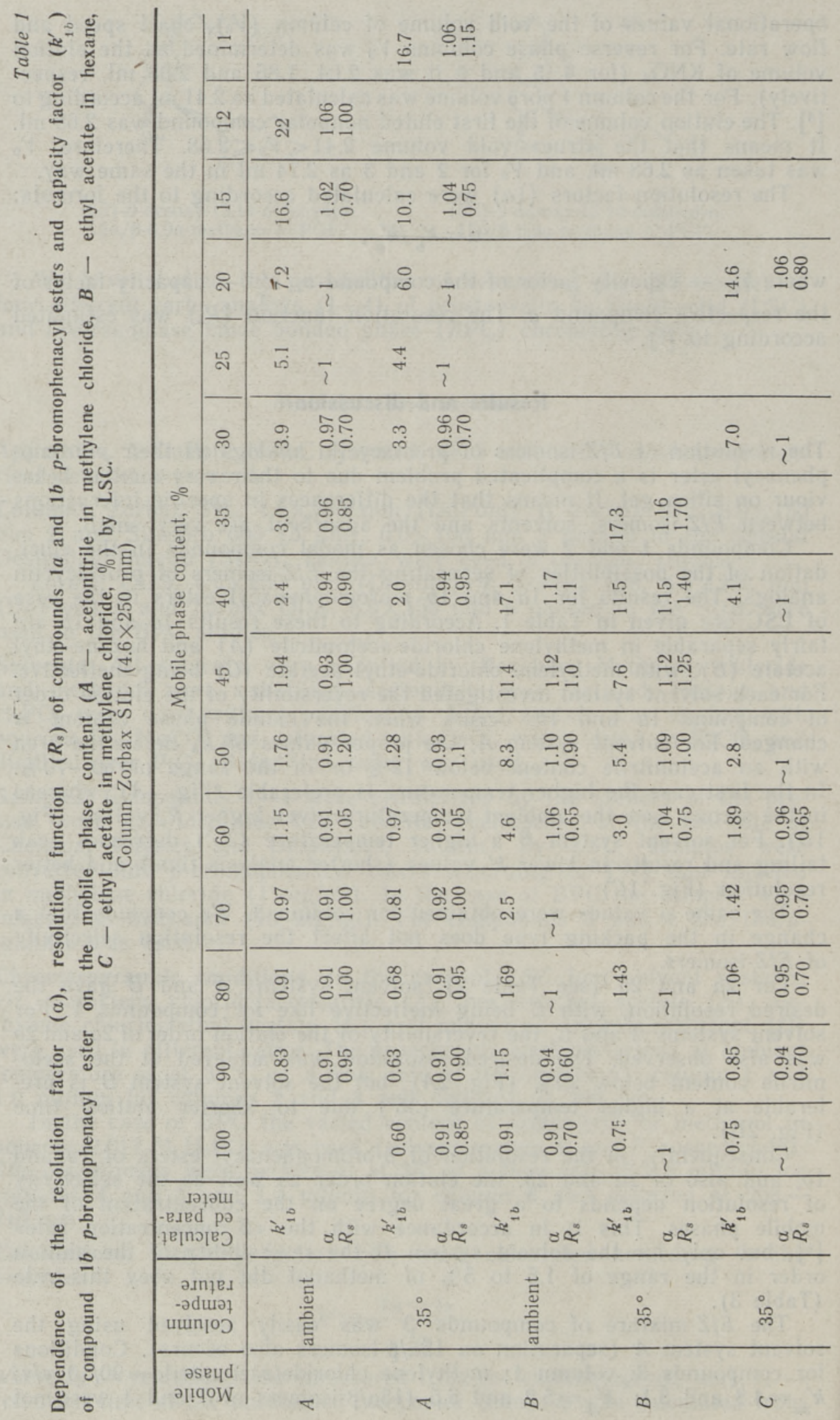


identified); $R_{s}$ values between these peaks are $1.05,0.70$ and 1.00 , respectively. Conditions for compounds 4 : column 2 ; methylene chloride/acetonitri-

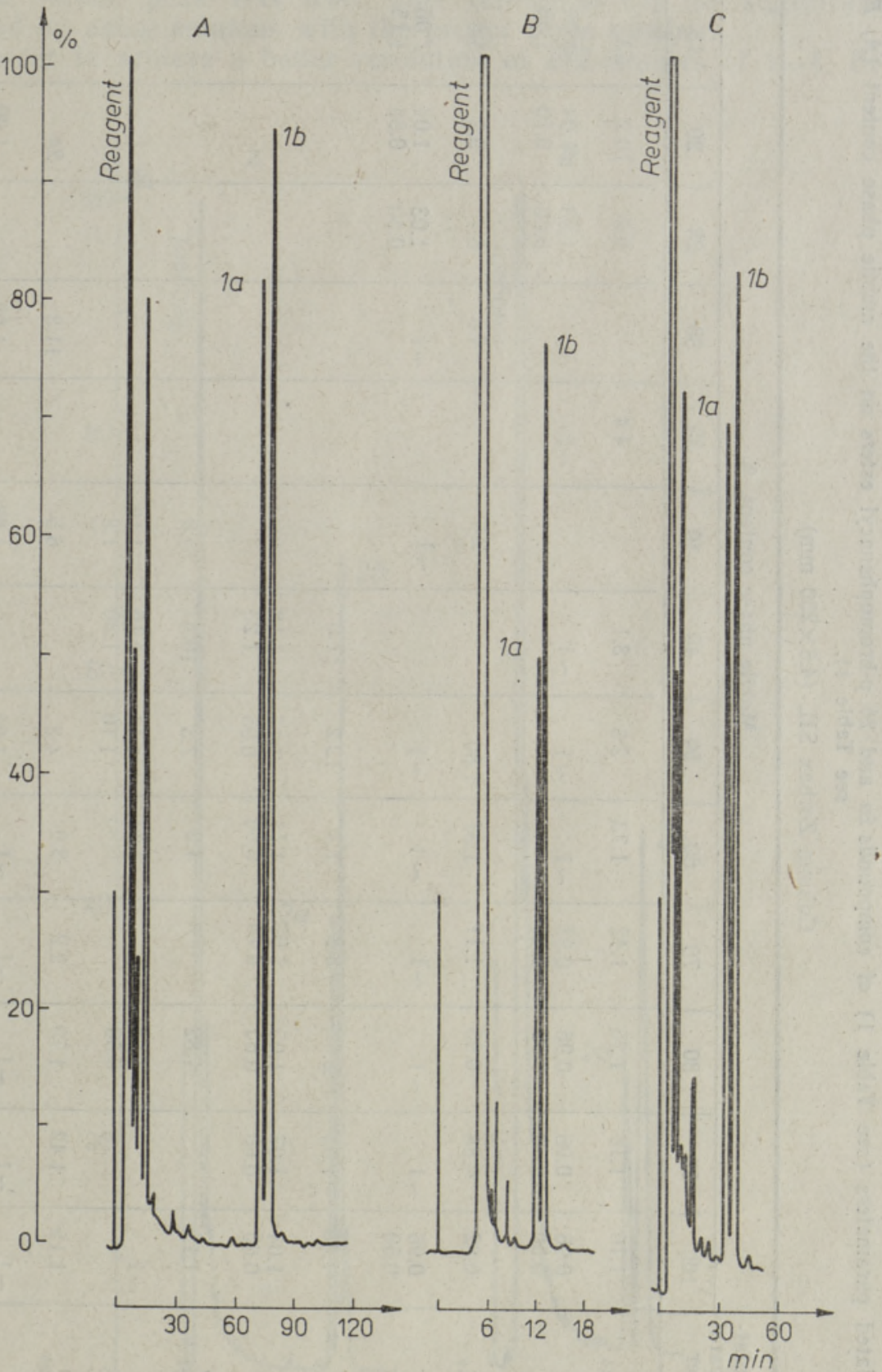

Fig. 1. Chromatograms of the separation of compounds $1 a$ and $1 b$ p-bromophenacyl Conditions: Column - Zorbax SIL $(4.6 \times 250 \mathrm{~mm})$; flow rate $-0.6 \mathrm{ml} / \mathrm{min}$; detection

$A$-mobile phase - methylene chloride/acetonitrile $=89 / 11$; column temperature $-35{ }^{\circ} \mathrm{C}$; absorbance - 0.32 AUFS; chart speed $-2.5 \mathrm{~cm} / \mathrm{h} ; \sim 8 \mu \mathrm{g}$ injected.

$B$-mobile phase - methylene chloride/acetonitrile $=50 / 50$; column temperature -ambient; absorbance - 0.64 AUFS; chart speed $-10 \mathrm{~cm} / \mathrm{h} ; \sim 4 \mu \mathrm{g}$ injected.

$C$-mobile phase - hexane/ethyl acetate $=55 / 45$; column temperature $-35{ }^{\circ} \mathrm{C}$; absorbance - 0.32 AUFS; chart speed $-2.5 \mathrm{~cm} / \mathrm{h} ; \sim 4 \mu \mathrm{g}$ injected. 


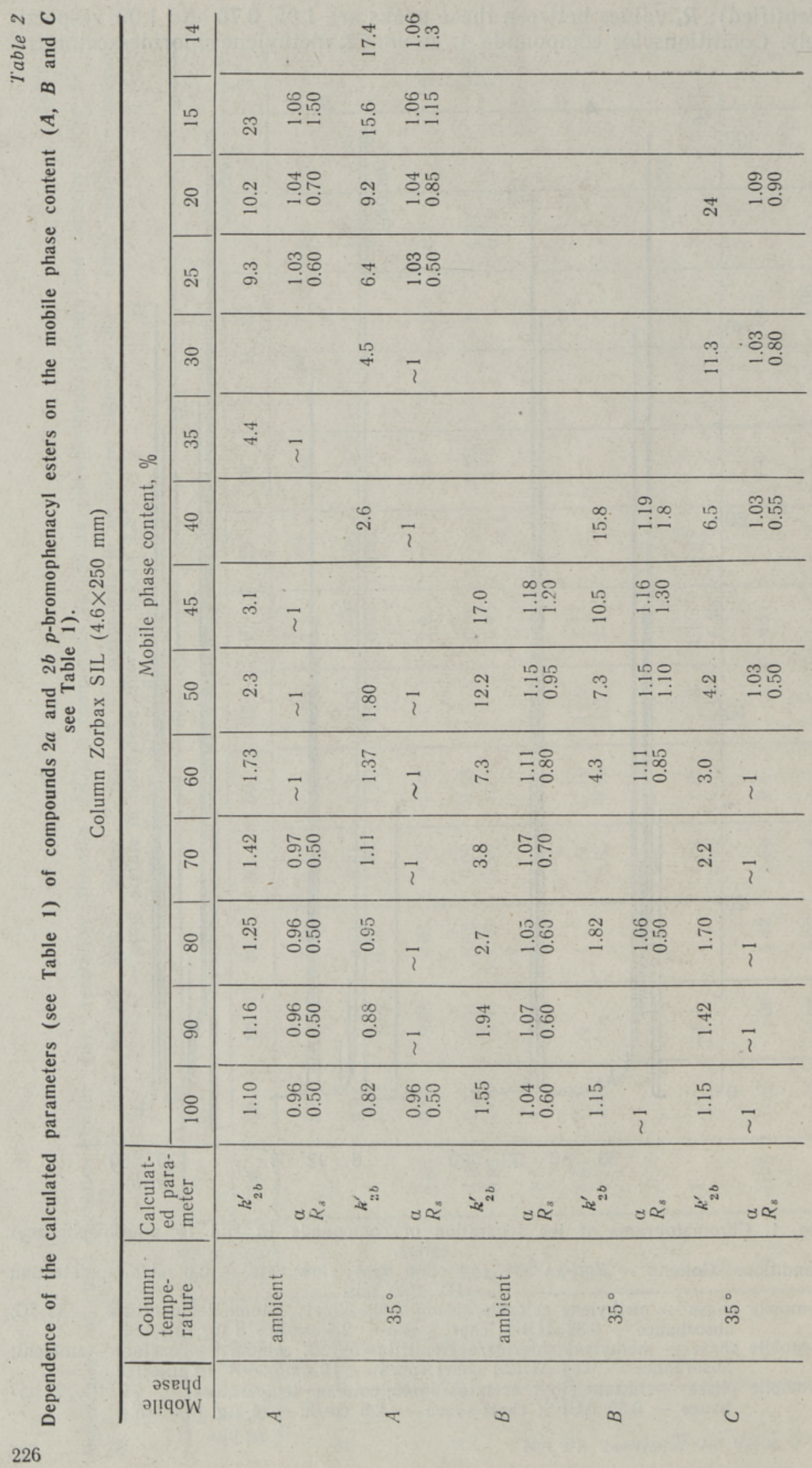


le $=85 / 15 \mathrm{v} / \mathrm{v} ; k_{4 a}^{\prime}=6.8$ and $7.5 ; \quad k_{4 b}^{\prime}=7.4$ and $7.6 ; R_{s}$ between the first and the second peak was 0.90 . This resolution can be significantly improved by using columns with the proper plate number.

In order to achieve a better resolution of $E / Z$-isomers of $1-4, \mathrm{BPC}$

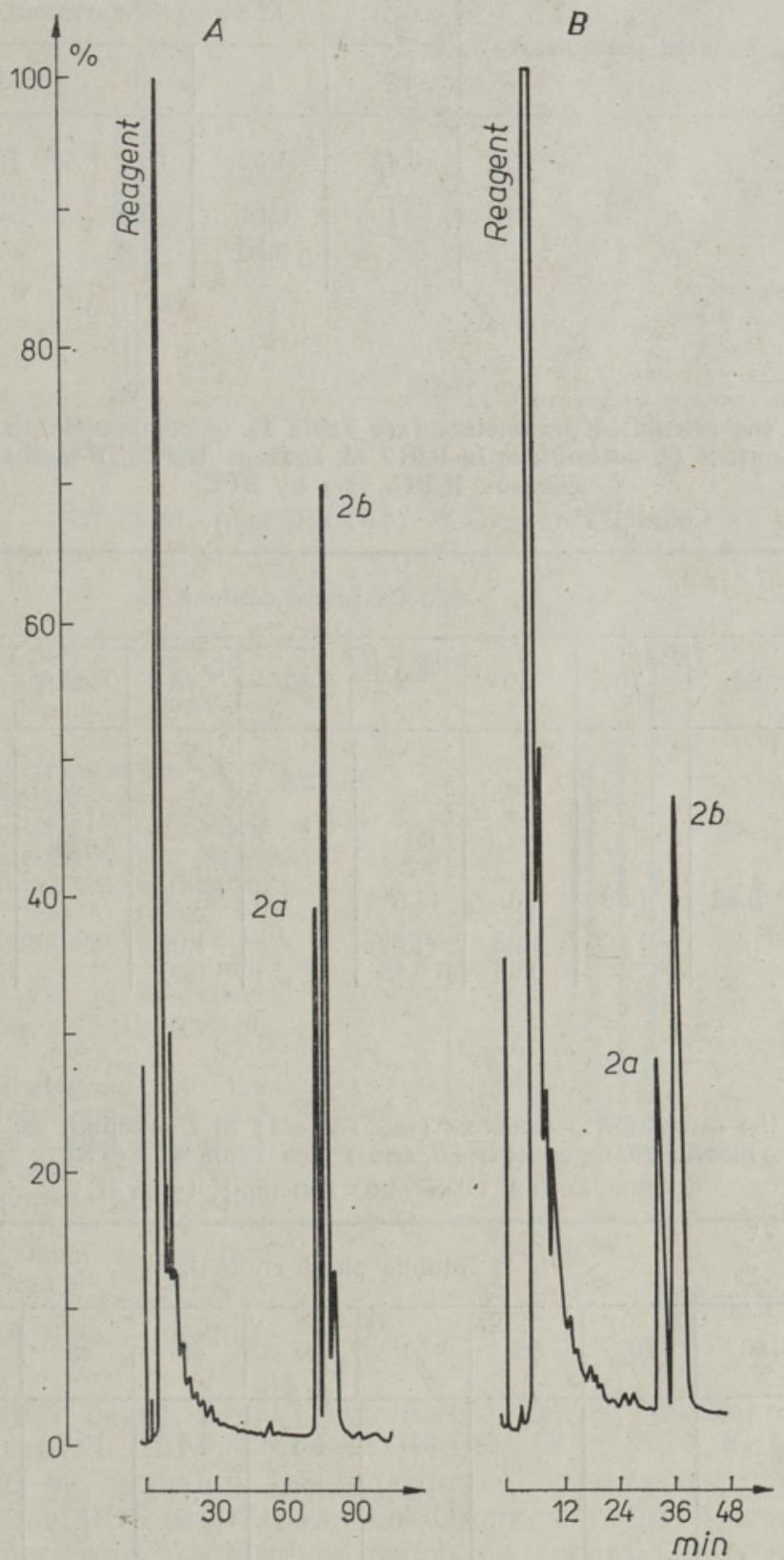

Fig. 2. Chromatograms of the separation of compounds $2 a$ and $2 \mathrm{~b}$ p-bromophenacyl esters.

Conditions: Column - Zorbax SIL $(4.6 \times 250 \mathrm{~mm})$; flow rate $-0.6 \mathrm{ml} / \mathrm{min}$; column temperature $-35^{\circ} \mathrm{C}$; detection - UV $260 \mathrm{~nm}$; absorbance -0.32 AUFS.

$A$-mobile phase - methylene chloride/acetonitrile $=86 / 14$; chart speed $2.5 \mathrm{~cm} / \mathrm{h} ; \sim 12 \mu \mathrm{g}$ injected.

$B$-mobile phase - hexane/ethyl acetate $=50 / 50$; chart speed $-5 \mathrm{~cm} / \mathrm{h} ; \sim 10 \mu \mathrm{g}$ injected. 
Dependence of the calculated parameters (see Table 1) of compounds $1 a$ and $1 b$ $p$-bromophenacyl esters on the mobile phase content $(D-$ methanol in methylene chloride, \%) by LSC.

Column Zorbax SIL $(6.0 \times 150 \mathrm{~mm}), \mathrm{t}=35{ }^{\circ} \mathrm{C}$

\begin{tabular}{l|c|c|c|c|c|c}
\hline \multirow{2}{*}{$\begin{array}{c}\text { Mobile } \\
\text { phase }\end{array}$} & Calculated parameter & \multicolumn{5}{|c}{ Mobile phase content, \% } \\
\cline { 2 - 6 } & & 10 & 5 & 3 & 2 & 1.5 \\
\hline \multirow{2}{*}{$k_{1 b}^{\prime}$} & 0.43 & 1.02 & 3.3 & 7.6 & 14.1 \\
& $\alpha$ & $\sim 1$ & 0.94 & 0.97 & $\sim 1$ & 1.02 \\
& $R_{s}$ & & 0.70 & 0.60 & & 0.55
\end{tabular}

Table 4

Dependence of the calculated parameters (see Table 1 ) of compounds $1 a$ and $1 b$ on the mobile phase content $\left(E\right.$-acetonitrile in $0.017 \mathrm{M}$ aqueous $\mathrm{H}_{3} \mathrm{PO}_{4}, F$-methanol in $0.017 \mathrm{M}$ aqueous $\mathrm{H}_{3} \mathrm{PO}_{4}, \%$ ) by BPC.

Column Zorbax ODS $(4.6 \times 250 \mathrm{~mm}), \mathrm{t}=35{ }^{\circ} \mathrm{C}$

\begin{tabular}{|c|c|c|c|c|c|c|c|c|c|c|}
\hline \multirow{2}{*}{ 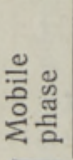 } & \multirow{2}{*}{ 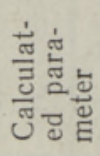 } & \multicolumn{9}{|c|}{ Mobile phase content, $\%$} \\
\hline & & 80 & 70 & 60 & 52 & 50 & 48 & 40 & 36 & 32 \\
\hline \multirow{3}{*}{ E } & $k_{1 b}^{\prime}$ & & & & & 2.6 & & 7.5 & 11.4 & 25 \\
\hline & $\begin{array}{l}\alpha \\
R_{s}\end{array}$ & & & & & $\sim 1$ & & $\begin{array}{l}1.05 \\
0.80\end{array}$ & $\begin{array}{l}1.07 \\
0.90\end{array}$ & $\begin{array}{l}1.07 \\
1.00\end{array}$ \\
\hline & $k_{1 b}^{\prime}$ & 0.82 & 1.22 & 5.3 & 15.5 & & 26 & & & \\
\hline$F$ & $\begin{array}{l}\alpha \\
R_{s}\end{array}$ & $\sim 1$ & $\sim 1$ & $\begin{array}{l}1.06 \\
0.85\end{array}$ & $\begin{array}{l}1.09 \\
0.95\end{array}$ & & $\begin{array}{l}1.09 \\
1.00\end{array}$ & & & \\
\hline
\end{tabular}

Table 5

Dependence of the calculated parameters (see Table 1) of compounds $2 a$ and $2 b$ on the mobile phase content $(E$ and $F$ see Table 4$)$ by BPC.

Column Zorbax ODS $(4: 6 \times 250 \mathrm{~mm}), \mathrm{t}=35{ }^{\circ} \mathrm{C}$

\begin{tabular}{|c|c|c|c|c|c|c|c|c|c|c|}
\hline \multirow{2}{*}{ 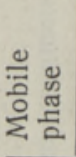 } & \multirow{2}{*}{ 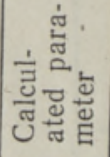 } & \multicolumn{9}{|c|}{ Mobile phase content, $\%$} \\
\hline & & 80 & 70 & 60 & 50 & 47 & 45 & 40 & 36 & 34 \\
\hline \multirow[b]{2}{*}{ E } & $k_{2 b}^{\prime}$ & & & & 3.3 & 4.3 & 5.3 & 10.0 & 15.6 & 24 \\
\hline & $\begin{array}{l}\alpha \\
R_{s}\end{array}$ & & & & $\begin{array}{l}1.03 \\
0.60\end{array}$ & $\begin{array}{l}1.05 \\
0.80\end{array}$ & $\begin{array}{l}1.11 \\
0.90\end{array}$ & $\begin{array}{l}1.12 \\
1.10\end{array}$ & $\begin{array}{l}1.14 \\
2.20\end{array}$ & $\begin{array}{l}1.15 \\
2.50\end{array}$ \\
\hline$F$ & $\begin{array}{l}k_{2 b}^{\prime} \\
a \\
R_{s}\end{array}$ & $\begin{array}{l}1.51 \\
1.08 \\
0.50\end{array}$ & $\begin{array}{l}2.4 \\
1.08 \\
0.90\end{array}$ & $\begin{array}{l}7.9 \\
1.15 \\
1.50\end{array}$ & & & & & & \\
\hline
\end{tabular}

was studied, using 1 and 2 as model compounds. These data are given in Tables 4 and 5 , respectively. It is rather difficult to obtain acceptable resolution of $1 a$ and $1 b$ on columns Zorbax ODS, but $2 a$ and $2 b$ are 


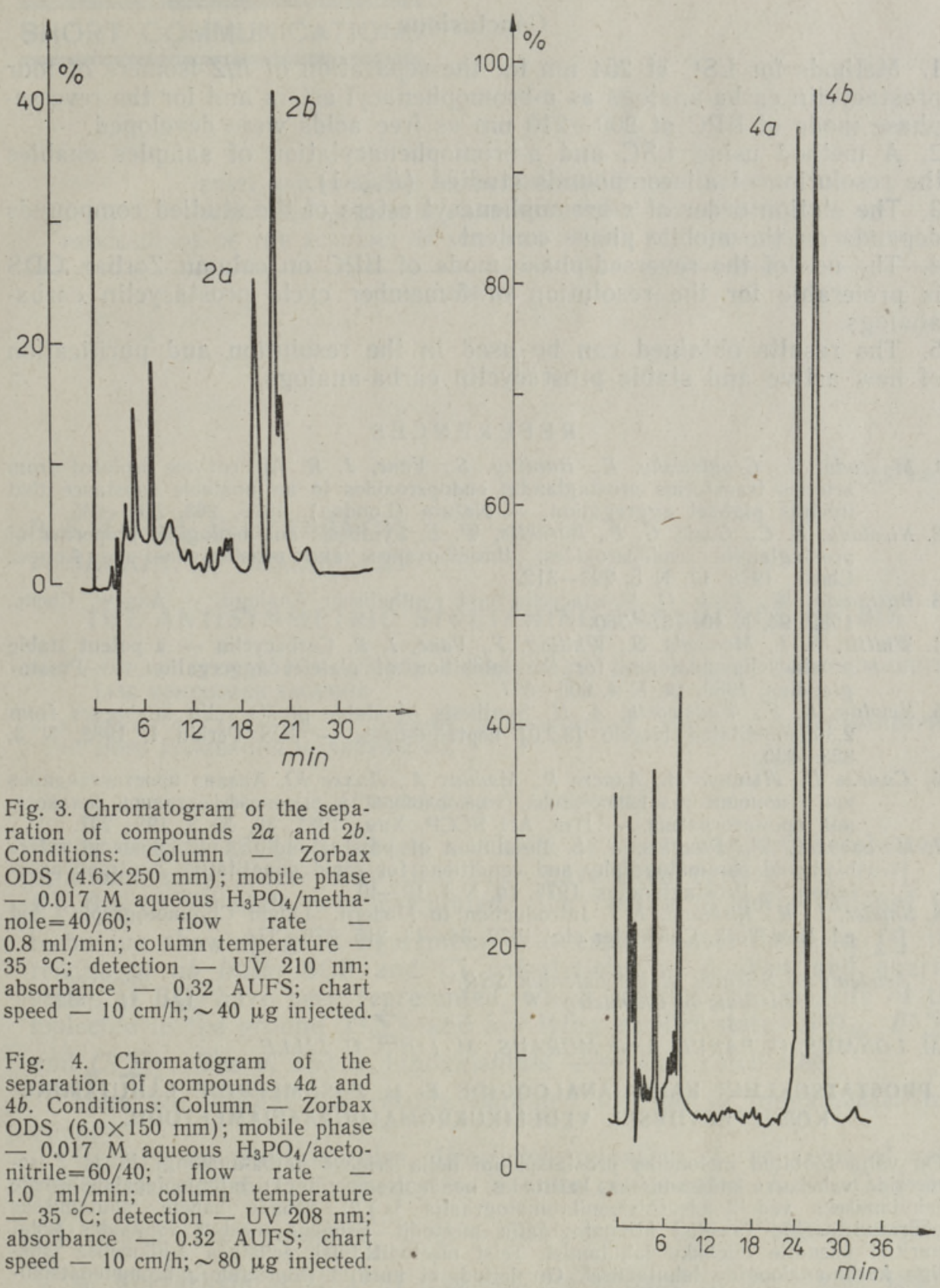

resolved easily, using either acetonitrile $(E)$ or methanol $(F)$ as a «strong» solvent in $0.017 \mathrm{M}$ aqueous $\mathrm{H}_{3} \mathrm{PO}_{4}$ (Fig. 3 ). A better resolution was achieved by methanol (peak tailing is diminished), but the «lifetime» of Zorbax ODS and Zorbax C-8 columns in this system is shorter. The $E / Z$-isomers of 3 are resolved poorly on Zorbax C-8 column (column $5 ; 0.017 \mathrm{M}$ aqueous $\mathrm{H}_{3} \mathrm{PO}_{4} /$ acetonitrile $=68 / 32 \mathrm{v} / \mathrm{v} ; \quad k_{3 a}^{\prime}=22 ; \quad k_{3 b}^{\prime}=21$; $\left.R_{s}=0.95\right)$ and similarly to 1 on Zorbax ODS column. Likewise, the resolution of 5-member cycle carba-analogs $4 a$ and $4 b$ is easily obtained on Zorbax ODS column (see conditions in Fig. 4). Zorbax C-8 column gives poorer results. The $15 \alpha / \beta$-isomers of these compounds were inseparable. 


\section{Conclusions}

1. Methods for LSC at $254 \mathrm{~nm}$ for the separation of $E / Z$-isomers of four prostacyclin carba-analogs as p-bromophenacyl esters and for the reversephase mode of BPC at $200-210 \mathrm{~nm}$ as free acids were developed.

2. A method using LSC and p-bromophenacylation of samples enables the resolution of all compounds studied $\left(R_{s} \geqslant 1\right)$.

3. The elution order of $p$-bromophenacyl esters of the studied compounds depends on the mobile phase content.

4. The use of the reversed-phase mode of BPC on column Zorbax ODS is preferable for the resolution of 5 -member cycle prostacyclin carbaanalogs.

5. The results obtained can be used in the resolution and purification of new active and stable prostacyclin carba-analogs.

\section{REFERENCES}

1. Moncada, S., Gryglewsky, R., Bunting, S., Vane, J. R. An enzyme isolated from arteries transforms prostaglandin endoperoxides to an unstable substance that inhibits platelet aggregation. - Nature (London), 1976, 263, 663-665.

2. Nicolaou, K. C., Gasic, G. P., Barnette, W. E. Synthesis and biological properties of prostaglandin endoperoxides, thromboxanes and prostacyclins. - Angew. Chem., 1978, 17, N 5, 293-312.

3. Bartmann, W., Beck, G. Prostacyclin und synthetische Analoga. - Angew. Chem., $1982,94, \mathrm{~N} 10,767-780$.

4. Whittle, B. J., Moncada, S., Whiting, F., Vane, J. R. Carbacyclin - a potent stable prostacyclin analogue for the inhibition of platelet aggregation. - Prostaglandins, 1980, 19, N 4, 605-627.

5. Newton, R. F., Wadsworth, A.H. Synthesis of stable prostacyclin analogues from 2,3-disubstituted bicyclo [3.2.0] heptan-6-ones. - JCS Perkin I, 1982, N 3, $823-830$.

6. Самель Н., Лыхмус М., Алисте Р., Мянник А., Лилле Ю. Анализ простагландинов при помощи газожидкостной, тонкослойной и высокоэффективной жидкостной хроматографии. - Изв. АН ЭССР. Хим., 1981, 30, № 3, 199-207.

7. Morozowich, W., Douglas, $S$. L. Resolution of prostaglandin $p$-nitrophenacyl esters by liquid chromatography and conditions for rapid quantitative $p$-nitrophenacylation. - Prostaglandins, 1975, 10, N 1, 19-40.

8. Snyder, L. R., Kirkland, J. J. Introduction to Modern Liquid Chromotography. 2nd ed. New York, Chichester etc., 1979, 38-43, 215, 370-374.

Academy of Sciences of the Estonian SSR, Institute of Chemistry

Received

Jan. 11. 1985

\section{LOHMUS, O. PARVE, Anne MORAUS, M. LOPP, O. LILLE}

\section{PROSTATSUKLIINI KARBA-ANALOOGIDE $E$ - ja $Z$-ISOMEERIDE LAHUTAMINE KORGEFEKTIIVSEL VEDELIKUKROMATOGRAAFIAMEETODIL}

On välja töötatud metoodika prostatsükliini nelja erineva karba-analoogi $E$ - ja $Z$-isomeeride vahekorra määramiseks, kasutades nende isomeeride 1) p-bromofenatsüülestrite lahutamiseks vedelik-adsorbtsioonikromatograafia ja 2) vabade hapete lahutamiseks pööratud seotud faasilist kromatograafia meetodit. Esimene meetod võimaldas kōigi uuritud ühendite täielikku lahutamist. Teist meetodit tuleb eelistada 5-liikmelise tsükliga karba-analoogide lahutamisel. On leitud, et uuritud isomeeride $p$-bromofenatsüülestrite elueerumisjärjekord silikageelil sōltub liikuva faasi koosseisust.

\section{М. ЛЫХМУС, О. ПАРВЕ, Анне МЮРАУС, М. ЛОПП, Ю. ЛИЛЛЕ \\ РАЗДЕЛЕНИЕ $\boldsymbol{E}$ - И $\boldsymbol{Z}$-ИЗОМЕРОВ КАРБА-АНАЛОГОВ ПРОСТАЦИКЛИНА МЕТОДОМ ВЫСОКОЭФФЕКТИВНОИ ЖИДКОСТНОИ ХРОМАТОГРАФИИ}

Разработана методика для анализа смесей $E$ - и $Z$-изомеров четырех карба-аналогов простациклина, заключающаяся в разделении их в виде $n$-бромофенациловых эфиров с помощью жидкостно-адсорбционной хроматографии и в виде свободных кислот с помощью химически связанной обращенно-фазовой хроматографии. Первый способ обеспечил полное разделение всех изученных соедннений. Второй способ предпочтительнее для разделения карба-аналогов с 5-членным циклом. Найдено, что порядок элюирования $n$-бромофенациловых эфиров исследованных изомеров на силикагеле зависит от состава подвижной фазы. 